\title{
Viewpoint \\ Regulation of cancer stem cells by p53
}

D Joseph Jerry ${ }^{1,2}$, Luwei Tao ${ }^{1}$ and Haoheng Yan ${ }^{1}$

\author{
1Department of Veterinary \& Animal Sciences, University of Massachusetts-Amherst, Amherst, MA 01003, USA \\ 2Pioneer Valley Life Sciences Institute, Springfield, MA 01199, USA
}

Corresponding author: D Joseph Jerry, jjerry@vasci.umass.edu

Published: 29 August 2008

This article is online at http://breast-cancer-research.com/content/10/4/304

(c) 2008 BioMed Central Ltd
Breast Cancer Research 2008, 10:304 (doi:10.1186/bcr2133)

\begin{abstract}
The hypothesis that cancer stem cells are responsible for the chemoresistant and metastatic phenotypes of many breast cancers has gained support using cell-sorting strategies to enrich the tumor-initiating population of cells. The mechanisms regulating the cancer stem cell pool, however, are less clear. Two recent publications suggest that loss of p53 permits expansion of presumptive cancer stem cells in mouse mammary tumors and in human breast cell lines. These results add restriction of cancer stem cells as a new tumor suppressor activity attributed to p53.
\end{abstract}

\section{Enrichment of tumor-initiating cells in p53-deficient mammary tumor models}

The recent identification and characterization of stem cells in a variety of adult tissues has led to renewed interest in the role of stem cells in cancers. Cancer stem cells are hypothesized to be a small population of cells within a tumor that are capable of self-renewal and that can undergo differentiation to generate the phenotypic heterogeneity observed in tumors. Contemporary methods for studying cancer stem cells have most often used cell surface markers to enrich the subset of cells capable of initiating a tumor upon transplantation into an appropriate host. Molecular pathways that limit expansion of the tumor-initiating cell population could be targeted to eradicate tumors.

Using mammary tumors arising spontaneously from transplants of BALB/c-Trp53-/- mammary epithelium, Zhang and coworkers show that cells expressing markers of mouse mammary stem cells (lin-/CD29hi/CD24hi) had a greater tumor-initiating frequency [1]. This observation was consistent among tumors with heterogeneous expression of markers for the luminal epithelium and the basal epithelium. The lin-/CD29hi/CD24hi population shared additional features of mammary stem cells, including radiation resistance and the formation of secondary mammospheres.

But how might loss of p53 lead to formation or expansion of the tumor-initiating pool? Using a unique culture model of luminal breast epithelial cells (BPEC-T), Godar and co- workers demonstrate that p53 binds to the promoter of CD44 [2], a commonly used marker of cancer stem cells [3], and represses CD44 expression. Constitutive expression of CD44 blocked p53-dependent apoptosis and rendered cells resistant to doxorubicin. Conversely, suppression of CD44 expression restricted tumor-initiating cells.

These results link the loss of p53 function to increased expression of CD44, which promotes expansion of tumorinitiating cells purified in tumors. The p53 protein appears to play a similar role in embryonic stem cells, where p53 represses expression of Nanog - which limits the pool of pluripotent cells $[4,5]$. In contrast, loss of p53 extends the repopulating activity of tissue-specific stem cells $[6,7]$. Disruption of BRCA1 also allows expansion of breast stem cells [8]. The restriction of stem cells may therefore be a fundamental pathway for tumor suppression.

\section{Reading between the cell lines}

While expansion of the tumor-initiating cell population in p53deficient mammary epithelial cells is consistent in both mouse mammary and human breast epithelial cells, the role of CD44 is not. Although loss of p53 expression resulted in increased levels of CD44 protein in BPEC-T cells and in basal mammary epithelium of $\operatorname{Trp}_{53^{-1}}$ mice [2], there was no enrichment for tumor-initiating cells within the CD44 ${ }^{+}$CD24population in BALB/c-Trp53-l- mammary tumors [1]. This apparent discrepancy points to heterogeneity in the expression of markers among cancer stem cells. In mammary tumors from Brca14Exon11/Trp53 $3^{+/-}$mice, two discrete tumor-initiating populations were identified that express either CD44+/CD24or $\mathrm{CD}_{133^{+}}$[9]. As coexpression of CD44 and CD133 was not detected in these pools of cells, it appears that CD44 is not essential for sustaining the pool of cancer stem cells.

Indeed, p53 represses expression of more than 20 target genes [10] that may contribute to maintenance of the pool of tumor-initiating cells. Genes such as Nanog may have direct actions in supporting self-renewal of cancer stem cells, allowing the pool to expand. Loss of p53 would also allow 
Figure 1

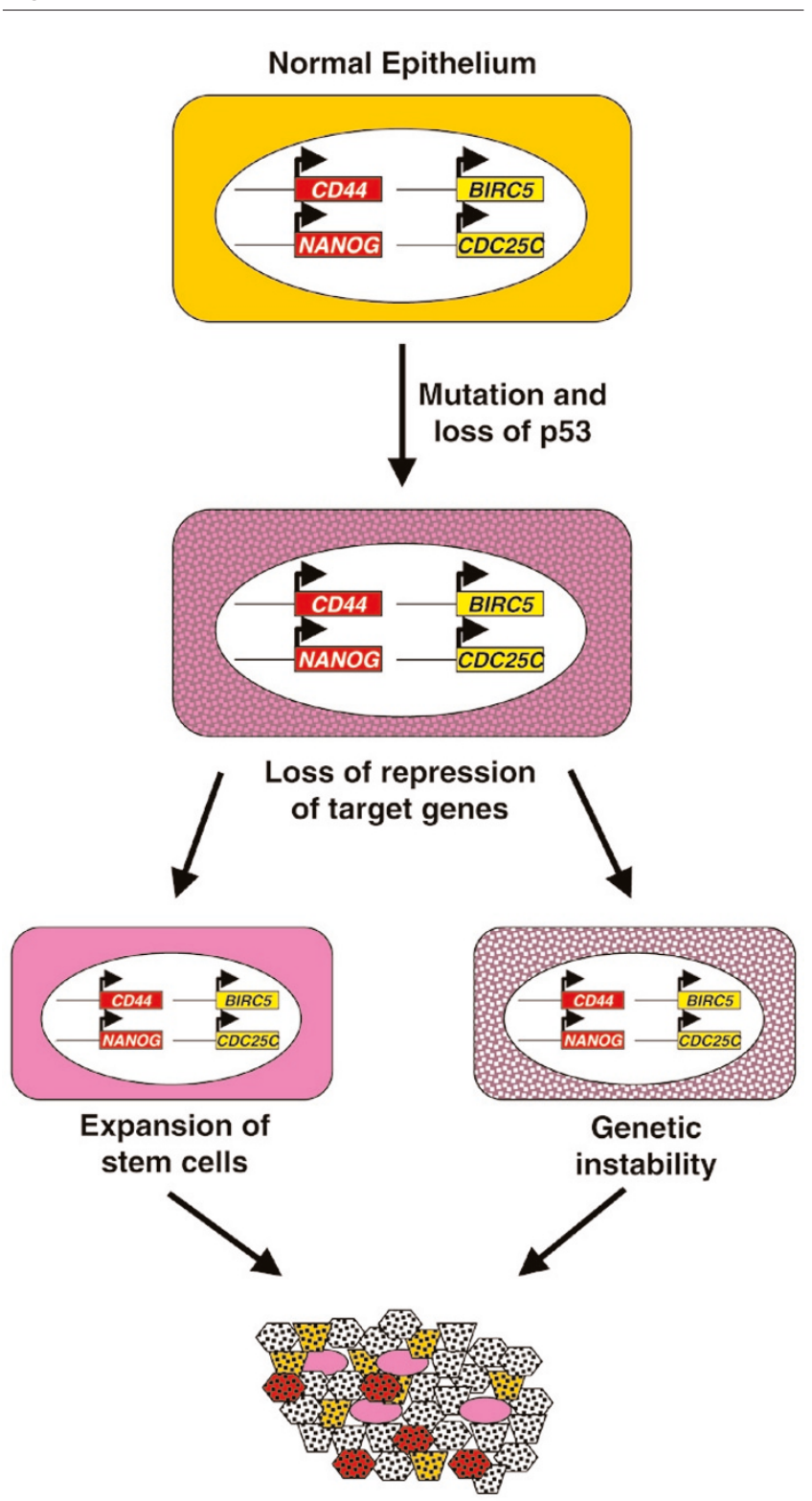

Tumor heterogeneity

Loss of p53 function and effects on tumor heterogeneity. In normal epithelia, p53 represses expression of potential oncogenes (for example, CD44, NANOG, BIRC5, CDC25C) as well as transcriptionally activating tumor suppressor pathways [10]. Loss of p53 allows genetic instability as well as expansion or acquisition of stem cell features during carcinogenesis. These pathways combine to generate the phenotypic heterogeneity and plasticity observed in tumors.

increased expression of the multidrug-resistance gene ( $A B C B 1$ or MDR1) that renders cells resistant to chemotherapies. Similarly, both increased proliferation and decreased apoptosis would be expected to result from derepression of CDC25C and BIRC5/Survivin when p53 function is disrupted. CD44 may therefore be only one mechanism by which p53 may act to restrict the tumorinitiating population of cancer cells.

\section{Cancer stem cells: puppet or puppeteer?}

It is clear that that p53 plays a pivotal role in tumor suppression. Mutation and loss of function of p53 are among the most common alterations in epithelial cancers [11], and gene expression signatures associated with dysfunctional p53 have been shown to predict patient survival $[12,13]$. The p53 protein regulates a variety of pathways (cell cycle arrest, apoptosis, DNA repair, senescence and autophagy) that can contribute to suppression of tumors. The publications by Zhang and colleagues and by Godar and colleagues now add suppression of cancer stem cells as an additional activity by which p53 can inhibit tumors [1,2]. So which of these pathways dominate? The answer will have significant impact on therapeutic strategies.

On the one hand, loss of p53 may promote genetic instability resulting in plasticity of phenotypes due to random mutations and clonal evolution (Figure 1). In this model, the behavior of the p53-deficient cancer cells would be stochastic and would require therapeutics targeting multiple oncogenic pathways. If the apparent phenotypic plasticity of p53-deficient breast tumors is due to the expansion of the cancer stem cell pool, however, therapies targeting the self-renewal pathways may be extremely effective. Loss of p53 function in breast tumors is strongly correlated with the basal-like gene expression signatures $[14,15]$. This suggest that either these tumors originate from breast stem cells or that loss of p53 allows cancer cells to acquire characteristics of stem cells. These results favor the possibility that p53 deficiency allows expansion of cancer stem cells and that the expression profiles of tumor-initiating cells will identify effective therapeutic targets.

\section{Competing interests}

The authors declare that they have no competing interests.

\section{References}

1. Zhang M, Behbod F, Atkinson RL, Landis MD, Kittrell F, Edwards D, Medina D, Tsimelzon A, Hilsenbeck S, Green JE, Michalowska $\mathrm{AM}$, Rosen JM: Identification of tumor-initiating cells in a p53null mouse model of breast cancer. Cancer Res 2008, 68:4674-4682.

2. Godar S, Ince TA, Bell GW, Feldser D, Donaher JL, Bergh J, Liu A, Miu K, Watnick RS, Reinhardt F, McAllister SS, Jacks T, Weinberg RA: Growth-inhibitory and tumor-suppressive functions of p53 depend on its repression of CD44 expression. Cell 2008, 134:62-73.

3. Al Hajj M, Wicha MS, Benito-Hernandez A, Morrison SJ, Clarke MF: Prospective identification of tumorigenic breast cancer cells. Proc Natl Acad Sci U S A 2003, 100:3983-3988.

4. Lin T, Chao C, Saito S, Mazur SJ, Murphy ME, Appella E, Xu Y: p53 induces differentiation of mouse embryonic stem cells by suppressing Nanog expression. Nat Cell Biol 2005, 7:165-171.

5. Oin H, Yu T, Qing T, Liu Y, Zhao Y, Cai J, Li J, Song Z, Qu X, Zhou $\mathrm{P}, \mathrm{Wu}$ J, Ding M, Deng H: Regulation of apoptosis and differentiation by p53 in human embryonic stem cells. J Biol Chem 2007, 282:5842-5852. 
6. Dumble M, Moore L, Chambers SM, Geiger H, Van ZG, Goodell MA, Donehower LA: The impact of altered p53 dosage on hematopoietic stem cell dynamics during aging. Blood 2007, 109:1736-1742.

7. Meletis K, Wirta V, Hede SM, Nister M, Lundeberg J, Frisen J: p53 suppresses the self-renewal of adult neural stem cells. Deve/opment 2006, 133:363-369.

8. Liu S, Ginestier C, Charafe-Jauffret E, Foco H, Kleer CG, Merajver SD, Dontu G, Wicha MS: BRCA1 regulates human mammary stem/progenitor cell fate. Proc Natl Acad Sci U S A 2008, 105:1680-1685.

9. Wright $\mathrm{MH}$, Calcagno AM, Salcido CD, Carlson MD, Ambudkar SV, Varticovski L: Brca1 breast tumors contain distinct $\mathrm{CD}^{4} 4^{+} / \mathrm{CD}^{2} 4^{-}$and $\mathrm{CD} 133^{+}$cells with cancer stem cell characteristics. Breast Cancer Res 2008, 10:R10.

10. Riley T, Sontag E, Chen P, Levine A: Transcriptional control of human p53-regulated genes. Nat Rev Mol Cell Biol 2008, 9:402-412.

11. Wood LD, Parsons DW, Jones S, Lin J, Sjoblom T, Leary RJ, Shen D, Boca SM, Barber T, Ptak J, Silliman N, Szabo S, Dezso Z, Ustyanksky V, Nikolskaya T, Nikolsky Y, Karchin R, Wilson PA, Kaminker JS, Zhang Z, Croshaw R, Willis J, Dawson D, Shipitsin M, Willson JK, Sukumar S, Polyak K, Park BH, Pethiyagoda CL, Pant PV, et al:: The genomic landscapes of human breast and colorectal cancers. Science 2007, 318:1108-1113.

12. Miller LD, Smeds J, George J, Vega VB, Vergara L, Ploner A, Pawitan Y, Hall P, Klaar S, Liu ET, Bergh J: An expression signature for p53 status in human breast cancer predicts mutation status, transcriptional effects, and patient survival. Proc Natl Acad Sci U S A 2005, 102:13550-13555.

13. Troester MA, Herschkowitz JI, Oh DS, He X, Hoadley KA, Barbier CS, Perou CM: Gene expression patterns associated with p53 status in breast cancer. BMC Cancer 2006, 6:276.

14. Langerod $A$, Zhao $H$, Borgan O, Nesland JM, Bukholm IR, Ikdahl T, Karesen R, Borresen-Dale AL, Jeffrey SS: TP53 mutation status and gene expression profiles are powerful prognostic markers of breast cancer. Breast Cancer Res 2007, 9:R30.

15. Herschkowitz JI, Simin K, Weigman VJ, Mikaelian I, Usary J, Hu Z, Rasmussen KE, Jones LP, Assefnia S, Chandrasekharan S, Backlund MG, Yin Y, Khramtsov Al, Bastein R, Quackenbush J, Glazer RI, Brown PH, Green JE, Kopelovich L, Furth PA, Palazzo JP, Olopade OI, Bernard PS, Churchill GA, Van DT, Perou CM: Identification of conserved gene expression features between murine mammary carcinoma models and human breast tumors. Genome Biol 2007, 8:R76. 